Огляди літератури, оригінальні дослідження, погляд на проблему, випадок з практики, короткі повідомлення УДК [616.441-002+616.29/.33-002.2-008.17]-053.6-078:57.083.3

DOI 10.11603/1811-2471.2020.v.i2.10974

\title{
РОЛЬ ЦИТОКІНОВОЇ ЛАНКИ У РЕАЛІЗАЦІї ЗАПАЛЬНОЇ РЕАКЦІЇ В ОСІБ МОЛОДОГО ВІКУ З ГАСТРОЕЗОФАГЕАЛЬНОЮ РЕФЛЮКСНОЮ ХВОРОБОЮ Й АВТОІМУННИМ ТИРЕОїДИТОМ
}

\section{Харківський національний медичний університет}

\author{
๑Т. М. Пасієшвілі
}

РЕЗЮмЕ. До захворювань внутрішніх органів, при яких запальна реакція запускає патогенетичну ланку формування та хронізації нозології, належать гастроезофагеальна рефлюксна хвороба (ГЕРХ) та автоімунний тиреоїдит (AIT). Їх поєднання в осіб молодого віку, незважаючи на доброякісний характер перебігу на початковому етапі, в подальшому може провокувати хронізацію процесу та формування ускладнень. Означені негаразди можуть бути наслідком змін імунної системи, а саме її цитокінової ланки.

Мета - дослідити стан та вивчити роль прозапальної ланки імунітету за вмістом каспази-1, ІЛ-1 $\beta$ і ІЛ-18 при ГЕРХ у осіб молодого віку з автоімунним тиреоїдитом.

Матеріал і методи. В обстеженні взяли участь 120 пацієнтів з ГЕРX і AІT та 45 осіб з ізольованою ГЕРX, віком від 18 до 25 років. Діагноз АІT підтверджували підвищеним вмістом антитіл до тиреопероксидази і тиреоглобуліну, а стан залози - дослідженням її гормонів. Наявність ГЕРХ, поряд з клінічною симптоматикою, доводили проведенням ЕФГДС з визначенням характеру ураження слизової оболонки. Вміст каспази-1, інтерлейкіну $1 \beta$ та інтерлейкіну 18 визначали в сироватці крові хворих імуноферментним методом.

Результати. Встановлено, що вміст каспази-1 у сироватці крові хворих на ізольовану ГЕРХ у 2,1 раза перевищував показник норми, та при приєднанні AІT збільшувався у 2,7 раза. Вміст ІЛ-1 $\beta$ також перевищував показники контролю у 3,9 та 6,5 раза відповідно. Вміст означених цитокінів залежав від стану слизової оболонки та був максимально збільшеним при наявності ерозивного процесу. Середній вміст ІЛ-18 у групі з коморбідною патологією перевищував показники норми майже у 8 разів $(p<0,05)$ проти трикратного збільшення у хворих на ізольовану ГEPX.

Висновки. Перебіг ГЕРХ та АІТ супроводжується підвищенням синтезу каспази-1, інтерлейкіну $1 \beta$ та інтерлейкіну 18, вміст яких залежить від морфологічних змін у слизовій оболонці стравоходу та не корелює з функцією щитоподібної залози. Підвищення інтерлейкіну 18 окрім участі у прозапальному процесі забезпечує автоімунний компонент AIT, що сприяє прогресуванню хвороби та формуванню ускладнень.

КлючОВІ СлОВА: гастроезофагеальна рефлюксна хвороба; автоімунний тиреоїдит; патогенез; цитокіни.

Вступ. Розвиток запальної реакції як природної захисної реакції організму на патоген при захворюваннях внутрішніх органів пов'язують із підвищенням синтезу прозапальних цитокінів. При цьому хронічний прогресуючий характер захворювань підпорядкований загальним законам патології - наявності генетично зміненого фону організму, при якому поєднання різних генотипів обумовлює особливості фенотипової симптоматики [1]. Цитокіни розглядають як месенджери запальних реакцій, які забезпечують розвиток адекватної і повноцінної відповіді організму і $\epsilon$ показниками динаміки запального процесу [2]. При цьому цитокіни потенціюють дві події: залучення у сферу захисної реакції інших клітин (епітеліальних, ендотеліальних, дендритних тощо) без обов'язкового їх контакту з патогеном, та «організацію» процесу міграції лейкоцитів з кровотоку в осередок запалення. Завдяки надходженню лейкоцитів до зони запалення реалізується повноцінна місцева захисна реакція силами факторів вродженого імунітету. Спочатку в осередок надходять більш мобільні нейтрофіли (макрофаги), яких найбільше-до 70 \%, що володіють фагоцитозом (полінуклеарна стадія запалення за І. І. Меч- ніковим) [3]. Потім, через 1-2 доби, мігрують моноцити, які диференціюються в макрофаги (мононуклеарна стадія); знову відбувається фагоцитоз не тільки патогенного і зруйнованого матеріалу, а й нейтрофілів; крім того, стимулюється проліферація клітин [4].

Отже, системне запалення, яке виникає внаслідок активного утворення прозапальних цитокінів, і місцевий процес, що розвивається у залученому до патології органі, завжди супроводжуються як загальноспрямованими реакціями, так і деякими особливостями. Останні розглядають як результат дії різноманітних причин у кожному конкретному випадку, коморбідності нозологій, генетичної і спадкової схильності [5].

Слід зазначити, що в більшості випадків при захворюваннях внутрішніх органів перша лінія захисту практично не забезпечує радикального видалення патогена, що викликав запалення. Якщо ж така нейтралізація зазначеного фактора відбувається, то на цьому реакції вродженого імунітету закінчуються. Розвиток другої лінії захисту пов'язують із початком адаптивної імунної відповіді. При цьому провідна роль у запуску останнього належить дендритним клітинам, макрофагам та іншим 
Огляди літератури, оригінальні дослідження, погляд на проблему, випадок з практики, короткі повідомлення професійним антиген-презентуючим клітинам, які відносяться до підсистеми вродженого імунітету і здійснюють процесинг і презентацію антигену [4].

Центральну роль у клітинному імунітеті в якості ініціатора запальної відповіді відіграє каспаза-1 (назва сімейства білків утворена поєднанням букв - англійська абрревіатура - суsteine-dependent aspartate specific protease - caspase), а також інтерлейкін-1-перетворювальний фермент - протеолітичний фермент, що $є$ еволюційно консервативним ферментом, який шляхом протеолізу розщеплює інші білки $[6,7]$. Після активації за допомогою утворення комплексу запалення каспаза ініціює захисну відповідь, при цьому запускається каскад прозапальних цитокінів, які забезпечують як місцеву, так і загальну реакцію організму. Прозапальний цитокін каспаза-1 $є$ першим активним компонентом запальної реакції, при цьому його функція зводиться не стільки до участі у процесах захисту, скільки до запуску повноцінної відповіді шляхом активації практично всієї системи цитокінів. У результаті утворення каспази-1 відбувається синтез інтерлейкіну $1 \beta$ (IL-1 $1 \beta$ ) та інтерлейкіну 18 (IL18), які, в свою чергу, додатково індукують запальну відповідь у сусідніх клітинах. При цьому загибель клітини в процесі запальної відповіді йде переважно шляхом піроптозу - запрограмованого літичного шляху смерті клітини $[8,9]$.

До захворювань внутрішніх органів, при яких запальна реакція запускає патогенетичну ланку формування та хронізації нозології, належить гастроезофагеальна рефлюксна хвороба (ГЕРХ). Підкоряючись класичним законам запалення, це захворювання набуває деяких особливостей. Розвиток запалення в стравоході може мати ерозивний або неерозивний характер, виникати на тлі езофагіту, поєднуватися з різними захворюваннями внутрішніх органів, формуватися в будь-якому віці й, що особливо примітно, несвоєчасно діагностуватися. Остання обставина пов'язана з пізнім зверненням пацієнтів як у результаті незнання клінічної симптоматики ГЕРХ, так і неуважності до окремих її проявів - печії, гіркоти у роті [10]. Важливе значення при цьому належить частому поєднанню з іншими захворюваннями, коли клінічні прояви супутньої патології «перекривають» прояви ГЕРХ.

В осіб молодого віку таким несприятливим фоном може служити автоімунний тиреоїдит (AIT) - захворювання, яке створює змінений імунний фон, призводить до прогресування не тільки ГЕРХ, а й автоімунного процесу.

Роботами останніх років показано, що як при ГЕРХ, так і при AІT, запальний процес у слизовій стравоходу і щитоподібній залозі здійснюється через запуск каскаду прозапальних цитокінів. При цьому кожен з уражених органів робить свій вне-

сок у патологічний процес, змінюючи кількісні і якісні пріоритети. Розвиток запалення в стравоході при ГЕРХ супроводжується підвищенням вмісту ФНП- $\alpha$ і ІЛ-1 $\beta$, рівні яких корелюють з характером морфологічних змін (ерозивний процес) [11-13].

Також доведено, що ФНП- $\alpha$ відіграє важливу роль у патогенезі автоімунних захворювань щитоподібної залози (ЩЗ): бере участь у розвитку запальної відповіді, стимулює проліферацію антигенспецифічних Т- і В- лімфоцитів, синтез глікозаміногліканів у ретробульбарних фібробластах, що сприяє розвитку ендокринної офтальмопатії при дифузному токсичному зобі (ДТЗ); підсилює експресію молекул адгезії на поверхні тиреоцитів [14]. В. В. Харінцев і співавт. показали, що у пацієнтів з ендокринною офтальмопатією збільшуються концентрації прозапальних цитокінів у сироватці - ІЛ-1 $\beta$, ІЛ-8 і ФНП- $\alpha$. При цьому в сльозовій рідині спостерігалося перевищення концентрацій досліджених цитокінів у 2,5-3 рази, порівняно $з$ сироваткою крові [15]. Також низкою авторів встановлено взаємозв'язок між рівнем цитокінів і вмістом тиреоїдних гормонів (особливо вільного тироксину - Т4) у хворих з автоімунними захворюваннями щитоподібної залози [16]. Виявлено кореляційну залежність між продукцією ІЛ-2 у хворих на ДТЗ та рівнями тиреоїдних гормонів, а саме: позитивну - з вільним трийодтироніном, негативну - з тиреотропним гормоном (ТТГ). Подібні взаємозв'язки визначалися між рівнем ІЛ-4 і вмістом тиреоїдних гормонів: ІЛ-4 позитивно корелював із рівнем вільного тироксину і вільного трийодтироніну і негативно - 3 тиреотропним гормоном [17]. Рядом дослідників у хворих, які знаходилися в стані субклінічного гіпотиреозу, виявлено підвищення рівнів ІЛ-8 та ІЛ-10. При цьому при досягненні величини ТТГ, характерної для еутиреозу, нормалізувалися також рівні цих цитокінів [18]. У роботі Е. Motylewska і співавт. було виявлено значне зниження у сироватці крові концентрації ІЛ-7, який відповідає за проліферацію і диференціювання Т- і В-лімфоцитів, у хворих з маніфестною формою ДТЗ, порівняно з групою контролю, а також із хворими в стадії ремісії цього захворювання [19]. Наведені результати стали підставою до проведення нашого дослідження, метою якого було дослідження стану та визначення ролі прозапальної ланки за вмістом каспази-1, ІЛ-1 і ІЛ-18 при ГЕРХ у осіб молодого віку з автоімунним тиреоїдитом.

Матеріал і методи дослідження. До роботи було залучено 120 пацієнтів з коморбідним перебігом ГЕРХ і АІT (основна група). 45 осіб з ізольованою ГЕРХ склали групу порівняння. Всі пацієнти були віком від 18 до 25 років. Групи обстежених мали гендерну відповідність (переважали жінки, 
Огляди літератури, оригінальні дослідження, погляд на проблему, випадок з практики, короткі повідомлення $77,5 \%$ і 75,56 \% відповідно), аналогічну форму і тривалість захворювання, а також належали до одного соціального прошарку - студенти різних вузів міста. 20 практично здорових осіб аналогічного віку, статі та соціального статусу увійшли до групи контролю.

При встановленні діагнозу ГЕРХ використовували рекомендації Монреальського консенсусу (2006р.), а також «Протокол ведення хворих ...» на це захворювання.

Оцінку стану слизової оболонки стравоходу проводили при ЕФГДС (система «Fuginon»). Діагноз формулювали з урахуванням Лос-Анджелеської класифікації; при цьому гістоморфологічні дослідження біоптатів слизової стравоходу дозволяли ідентифікувати запальний характер захворювання.

Автоімунний тиреоїдит встановлювали на підставі скарг хворих, змін у щитоподібній залозі при пальпації, даних ультразвукового дослідження ЩЗ із використанням стандартної методики. Також визначали показники тестів на антитіла до тиреопероксидази і тиреоглобуліну, а функцію залози встановлювали за вмістом тиреотропного гормону, вільного тироксину і вільного трийодтироніну. Діагноз формулювали з урахуванням «Протоколів ведення хворих з АІT».

У дослідженні дотримувалися лікувально-діагностичних стандартів і вимог до етичної складової клінічних досліджень (GCP, 1997), законодавства України про охорону здоров'я, Гельсінської декларації 2000 року і директив Європейського товариства 86/609 щодо участі людей у медикобіологічних дослідженнях.

Активність каспази-1 визначали в сироватці крові імуноферментним методом з використанням комерційної тест-системи виробництва "Elabscience» (ELISA, CША) на імуноферментному аналізаторі «Labline-90» (Австрія) відповідно до інструкції. Вміст ІЛ-1 $\beta$ і ІЛ-18 досліджували з використанням комерційних наборів «Bender MedSystems $\mathrm{GmbH»} \mathrm{(Австрія)} \mathrm{згідно} \mathrm{з} \mathrm{запропонованими}$ методиками.

Статистичну обробку даних проводили за допомогою пакета програм загального призначення STATISTICA. Також використовували методи непараметричної статистики: критерій КраскелаУолліса, медіанний тест, критерій Манна-Уїтні.

Результати й обговорення. Проведене візуальне дослідження слизової оболонки стравоходу у пацієнтів основної групи дозволило в 28,3\% випадків (34 хворих) встановити ерозивну форму захворювання. Такі ж зміни у слизовій оболонці спостерігали і в 11 пацієнтів (24,4%) групи порівняння. При цьому в обох групах визначалося від 2-3 до 8-10 ерозій з частішою їх локалізацією в середній і нижній третинах стравоходу. У 40,8 \% хворих основної групи і 37,8 \% групи порівняння одночасно діагностували езофагіт. Рівні антитіл до тиреопероксидази і тиреоглобуліну перевищували показники норми, що підтверджувало автоімунний характер ураження ЩЗ. При цьому гормональна функція органа, з урахуванням вмісту тиреотропного гормону, вільного тироксину і вільного трийодтироніну, не змінювалася.

Дослідження вмісту каспази-1 у сироватці крові в осіб з поєднаним перебігом ГЕРX і AІT дало підстави говорити про їі вірогідне збільшення (у 2,7 раза) по відношенню до норми, що відповідає ії ролі в організмі - участі у формуванні запальної відповіді на первинному етапі системного процесу. У групі осіб з ізольованою ГЕРХ рівень каспази-1 також перевищував контрольні величини, хоча i мав відмінності від основної групи осіб (табл. 1).

Таблиця 1. Вміст каспази-1 у обстежених пацієнтів

\begin{tabular}{|c|c|c|c|}
\hline Показник & $\begin{array}{c}\text { Основна група } \\
(n=120)\end{array}$ & $\begin{array}{c}\text { Група порівняння } \\
(\mathrm{n}=45)\end{array}$ & $\begin{array}{c}\text { Контрольна група } \\
(\mathrm{n}=20)\end{array}$ \\
\hline Каспаза 1 (пг/мл) & $\begin{array}{c}1394,284 \\
(1155,198 ; 1517,132) *\end{array}$ & $\begin{array}{c}1238,901 \\
(921,3211 ; 1478,45) *\end{array}$ & $\begin{array}{c}510,7821 \\
(311,8725 ; 618,3146)\end{array}$ \\
\hline
\end{tabular}

Примітка. *p<0,01 при порівнянні з контрольною групою.

При цьому активність каспази-1 мала залежність від морфологічної форми ураження стравоходу. Так, у пацієнтів основної групи з ерозивною формою захворювання активність каспази-1 дорівнювала $1433,546(930,401 ; 1675,13)$ пг/мл. У хворих з ГЕРХ без ерозивного ураження стравоходу вміст означеного цитокіну дорівнюав 1170,038 $(1021,748 ; 1262,610)$ пг/мл $(p<0,05)$. Такі відмінності в зміні зазначеного показника при ерозивному процесі, на нашу думку, були результатом залучен- ня до патологічного процесу не тільки слизового шару, а й більш глибоких шарів стінки стравоходу, а також судинного русла. Таким чином, високі рівні каспази-1 асоціюються з більшою виразністю гістологічних змін і участю додаткових клітин і тканин. Тобто, на тлі імунного системного запалення і ерозивного ураження слизової формується ендотеліальна дисфункція, яка й збільшує показник каспази-1.

Рівень ІЛ-1 $\beta$ також перевищував показники контролю в обох групах обстежених (табл. 2). 
Огляди літератури, оригінальні дослідження, погляд на проблему, випадок з практики, короткі повідомлення Таблиця 2. Вміст прозапальних цитокінів у обстежених пацієнтів

\begin{tabular}{|l|c|c|c|}
\hline \multicolumn{1}{|c|}{ Цитокін (пг/мл) } & $\begin{array}{c}\text { Основна група } \\
(\mathrm{n}=120)\end{array}$ & $\begin{array}{c}\text { Група порівняння } \\
(\mathrm{n}=45)\end{array}$ & $\begin{array}{c}\text { Контрольна група } \\
(\mathrm{n}=20)\end{array}$ \\
\hline ІЛ-1 $\beta$ & $29,6(21,9 ; 35,5)^{*}$ & $17,7(15,9 ; 19,3)^{*}$ & $4,5(3,1 ; 6,3)$ \\
\hline ІЛ-18 & $1763,4(1451,7 ; 2879,2)^{*}$ & $614,9(521,9 ; 721,8)^{*}$ & $229,4(198,31 ; 269,37)$ \\
\hline
\end{tabular}

Примітка. *p<0,05 при порівнянні з контролем.

Встановлено, що величина ІЛ-1ß мала залежність від візуальної морфологічної картини: найбільші зміни показників цього цитокіну спостерігалися при ерозивній формі захворювання: його підвищення відповідало 32,8 $(24,9 ; 35,4)$ пг/мл в основній групі і $18,4(17,1 ; 19,3)$ пг/мл у групі порівняння.

Отже, поєднаний перебіг ерозивного езофагіту на тлі AІT характеризувався підвищеним вмістом прозапальних цитокінів, рівень яких перевищував середні показники у групі при неерозивній формі ГЕРХ. Можна припустити, що при розвитку ерозій у слизовій оболонці активується не тільки місцева запальна реакція, а й «включається» системна цитокін-опосередкована реакція організму. У такій ситуації формується хибне коло: макрофаги, що в підвищеній кількості надходять до місця запалення (локальний рівень), збільшують синтез ІЛ-1 $\beta$. Останній стимулює ґенез та атракцію нових генерацій макрофагів і моноцитів й переводить запалення на системний рівень.

Середній вміст ІЛ-18 в основній групі осіб перевищував показники норми майже в 8 разів $(p<0,05)$ та у групі хворих з ізольованою ГЕРХ - у 2,7 раза, тобто його активність була нижчою, ніж в осіб із поєднанням ГЕРX і AIT $(p<0,05)$. Ерозивна форма ГЕРХ характеризувалася помірним збільшенням вмісту даного цитокіну до 1975,7 (1631,4; $2798,9)$ пг/мл, порівняно з середнім показником у групі. Таким чином, підвищення синтезу ІЛ-18 у хворих з ізольованою ГЕРХ $є$ очікуваним результатом розвитку захисної запальної реакції. Статистично значуще підвищення вказаного показника при коморбідності ГЕРХ та AІT, мабуть, є не тільки результатом запальної реакції, а й зміненого імунного фону - автоімунного запалення. Тобто, через активацію Т-хелперів в присутності ІЛ-18 посилюється синтез В-лімфоцитів і, отже, збільшується й продукція антитіл. Такий механізм впливу інтерлейкіну 18 на імунні процеси обумовлює розвиток гіперчутливості сповільненого типу [20]. Тобто, незважаючи на відсутність клінічної симптоматики при AIT і збереженні нормальних показників тиреоїдних гормонів, має місце латентний перебіг захворювання, що буде не тільки підтримувати запалення в слизовій стравоходу, але й в кінцевому підсумку забезпечить прогресування AIT з порушенням функції щитоподібної залози.

Висновки. Поєднаний перебіг ГЕРХ та АIT призводить до формування системного запалення, що підтверджується посиленням синтезу каспази-1 і інтерлейкіну $1 \beta$. Рівні каспази-1 та інтерлейкіну $1 \beta$ залежать від морфологічних змін у слизовій стравоходу (збільшуються при ерозивній формі захворювання) і не корелюють із функціональним станом щитоподібної залози.

Перебіг ГЕРХ супроводжується підвищенням синтезу інтерлейкіну 18, активність якого достовірно збільшується при приєднанні АІT. Активність інтерлейкіну 18 при АІТ у хворих з ГЕРХ свідчить не тільки про розвиток запалення, а й про автоімунний механізм патології, що, в свою чергу, буде сприяти прогресуванню захворювань і формуванню ускладнень.

Перспективи подальших досліджень. У наступних роботах передбачається подальше визначення інших патогенетичних ланок поєднаного перебігу ГEPX та AIT.

\section{ЛІТЕРАТУРА}

1. Zhang J. M. Cytokines, inflammation, and pain / J. M. Zhang, J. An // International anesthesiology clinics. - 2007. - No. 45 (2). - P. 27-37. DOI: 10.1097/AIA.0b013e318034194e

2. PenningtonCytokines and chemokines: At the crossroads of cell signalling and inflammatory disease, Biochimica et Biophysica Acta (BBA) / Mark D. Turner, Belinda Nedjai, Tara Hurst, J. Daniel // Molecular Cell Research. - 2014. - No. 1843 (11). - P. 2563-2582. DOI: 10.1016/j.bbamcr.2014.05.014

3. Ковалёва А. А. И. И. Мечников - основатель теории старения и учения о пробиотиках / А. А. Ковалёва,
М. М. Великая // Пробл. старения и долголетия. 2016. - № 25 (1). - С. 11-22.

4. Черешнев В. А. Иммунологичные механизмы локального воспаления / В. А. Черешнев, М. В. Черешнева // Медицинская иммунология. - 2011. - № 13 (6). С. 557-568. DOI: 10.15789/1563-0625-2011-6-557-568

5. Markers of systemic inflammation and environmental enteric dysfunction are not reduced by zinc or multivitamins in Tanzanian infants: A Randomized, Placebo-Controlled Trial / Laver Jacqueline M. [et al.] // The Journal of Pediatrics. - 2019. - No. 210. - P. 34-40. DOI: 10.1016/j.jpeds.2019.02.016 
Огляди літератури, оригінальні дослідження, поглядн

6. Regulation and Function of the Caspase-1 in an Inflammatory Microenvironment / D. J. Lee, F. Du, S. W. Chen [et al.] // The Journal of investigative dermatology. - 2015. No. 135 (8). - P. 2012-2020. DOI: 10.1038/jid.2015.119

7. Caspase-1 initiates apoptosis in the absence of gasdermin D / K. Tsuchiya, S. Nakajima, S. Hosojima [et al.] // Nat Commun. - 2019. - No. 10. - P. 2091. DOI: $10.1038 / \mathrm{s} 41467-019-09753-2$

8. Arend W. P. IL-1, IL-18, and IL-33 families of cytokines / W. P. Arend, G. Palmer, C. Gabay // Immunol. Rev. - 2008. - No. 223. - P. 20-38. DOI: 10.1111/j.1600-065X. 2008.00624.x

9. Cytokines for evaluation of chronic inflammatory status in ageing research: reliability and phenotypic characterization / L. Koelman, O. Pivovarova-Ramich, A. F. H. Pfeiffer [et al.] // Immun Ageing. - 2019. - No. 16. P. 11. DOI: 10.1186/s12979-019-0151-1

10. Gastroesophageal reflux disease: Update on inflammation and symptom perception / A. Altomare, M. P. Guarino, S. Cocca [et al.] // World Journal of Gastroenterology. - 2013. - No. 19 (39). - P. 6523-6528. DOI: $10.3748 /$ wjg.v19.i39.6523

11. Пасієшвілі Т. М. Оцінка особливостей змін та діагностичної інформативності цитокінового профілю в осіб молодого віку з гастроезофагеальною рефлюксною хворобою, що протікає на тлі автоімунного запалення / Т. М. Пасієшвілі // Український терапевтичний журнал. - 2019. - № 3. - С. 16-21. DOI: 10.30978/UTJ2019-3-16

12. Plasma levels of TNF- $\alpha$, IL-6, IFN- $\gamma$, IL-12, IL-17, IL-22, and IL-23 in achalasia, eosinophilic esophagitis (EoE), and gastroesophageal reflux disease (GERD) / S. Clayton, E. Cauble, A. Kumar [et al.] // BMC gastroenterology. - 2019. No. 19 (1). - P. 28. DOI: 10.1186/s12876-019-0937-9

13. Пасієшвілі Т. М. Аутоиммунная и вегетативная обусловленность пролонгации восстановительного проблему, випадок з практики, короткі повідомлення периода у лиц молодого возраста с коморбидностью гастроэзофагеальной рефлюксной болезни и аутоиммунного тиреоидита / Т. М. Пасієшвілі // Клиническая и экспериментальная медицина. - 2019. - № 2 (151). C. 143-146. DOI: 10.29254/2077-4214-2019-2-2-151-143-147

14. Jones B. Effect of radioactive iodine therapy on cytokine production in Graves' disease: transient increase in IL-4, IL-6, IL-10 and TNF-alpha, with longer term increase in IFN-gamma production / B. Jones, C. Kwok, A. Kung // J. Clin. Endocrinol. Metab. - 1999. - No. 84. - P. 4106-4110.

15. Роль некоторых про- и противовоспалительных цитокинов в течении эндокринной офтальмопатии / В. В. Харинцев, О. В. Серебрякова, Д. М. Серкин [и др.] // Забайкальский медицинский вестник. - 2013. - № 1. C. $33-40$.

16. The relationship between thyroid function, serum monokine induced by interferon-gamma and soluble interleukin-2 receptor in thyroid autoimmune diseases / J. Jiskra, M. Antošová, Z. Límanová [et al.] // Clin. Experiment. Immunol. - 2009. - 156. - P. 211-216/

17. Саприна Т. В. Особенности продукции и рецепции цитокинов Th1/Th2-профиля при болезни Гревса / Т. В. Саприна, Т. С. Прохоренко, В. М. Резцова // Клиническая и экспериментальная тиреоидология. - 2012. № 8 (2). - С. 43-49.

18. Попова Е. В. Цитокиновый и тиреоидный профили при эндемическом зобе у лиц Южно-Уральского региона / Е. В. Попова, А. И. Смолягин, В. М. Боев // Цитокины и воспаление. - 2013. - № 12 (1). - С. 102-107.

19. Decreased serum level of IL-7 in patients with active Graves' disease / E. Motylewska, M. Nieć, A. Siejka [et al.] // Cytokine. - 2015. - No. 75 (2). - P. 373-379.

20. Насонов Е. Л. Роль интерлейкина 1 в развитии заболеваний человека / Е. Л. Насонов, М. С. Елисеев // Научно-практическая ревматология. -2016. - № 54 (1).C. 60-77.

\section{REFERENCES}

1. Zhang, J. M., \& An, J. (2007). Cytokines, inflammation, and pain. International Anesthesiology Clinics, 45 (2), 27-37. Retrieved from: https://doi.org/10.1097/ AIA.0b013e318034194e

2. Mark D. Turner, Belinda Nedjai, Tara Hurst, Daniel J. Pennington, (2014). Cytokines and chemokines: At the crossroads of cell signalling and inflammatory disease, Biochimica et Biophysica Acta (BBA), 1843 (11), 2563-2582. Retrieved from: https://doi.org/10.1016/j.bbamcr.2014.05.014

3. Kovaleva, A.A., \& Velykaya, M.M. (2016) I. I. Mechnikov - osnovatel teorii stareniya i ucheniya o probiotikakh [I. I. Mechnikov - founder of ageing and learning about probiotics]. Probl. stareniya i dolgoletiya - Problems of Ageing and Longevity, 25 (1), 11-22 [in Russian].

4. Chereshnev, V.A., \& Chereshneva, M.V. (2011). Immunological mechanisms of local inflammation. Medical Immunology (Russia), 13 (6), 557-568 [in Russian]. Retrieved from: https://doi.org/10.15789/1563-06252011-6-557-568

5. Lauer, Jacqueline M. (2019). Markers of systemic inflammation and environmental enteric dysfunction are not reduced by zinc or multivitamins in Tanzanian in-

fants: A Randomized, Placebo-Controlled Trial. The Journal of Pediatrics, 210, 34-40. Retrieved from: https://doi. org/10.1016/j.jpeds.2019.02.016

6. Lee, D. J., Du, F., Chen, S. W., Nakasaki, M., Rana, I., Shih, V., Hoffmann, A., \& Jamora, C. (2015). Regulation and function of the Caspase-1 in an inflammatory microenvironment. The Journal of Investigative Dermatology, 135 (8), 2012-2020. Retrieved from: https://doi.org/10.1038/ jid.2015.119

7. Tsuchiya, K., Nakajima, S., \& Hosojima, S. (2019). Caspase-1 initiates apoptosis in the absence of gasdermin D. Nat. Commun., 10, 2091. Retrieved from: https://doi. org/10.1038/s41467-019-09753-2

8. Arend, W.P., Palmer, G., \& Gabay, C. (2008). IL-1, IL-18, and IL-33 families of cytokines Immunol. Rev., 223, 20-38. Retrieved from: https://doi.org/10.1111/j.1600065X.2008.00624.x

9. Koelman, L., Pivovarova-Ramich, O., \& Pfeiffer, A.F.H. (2019). Cytokines for evaluation of chronic inflammatory status in ageing research: reliability and phenotypic characterisation. Immun. Ageing, 16, 11. Retrieved from: https://doi.org/10.1186/s12979-019-0151-1. 
Огляди літератури, оригінальні дослідження, погляд на проблему, випадок з практики, короткі повідомлення

10. Altomare, A., Guarino, M. P., Cocca, S., Emerenziani, S., \& Cicala, M. (2013). Gastroesophageal reflux disease: Update on inflammation and symptom perception. World Journal of Gastroenterology, 19 (39), 6523-6528. Retrieved from: https://doi.org/10.3748/wjg.v19.i39.6523

11. Pasiieshvili, T.M. (2019) Otsinka osoblyvostei zmin ta diahnostychnoi informatyvnosti tsytokinovoho profiliu v osib molodoho viku z hastroezofahealnoiu refliuksnoiu khvoroboiu, shcho protikaie na tli avtoimunnoho zapalennia [Evaluation of changes and diagnostic informative cytokine profile in young patients with gastroesophageal reflux disease, occurring against background of autoimmune inflammation]. Ukrainskyi terapevtychnyi zhurnal - Ukrainian Therapetic Journal, 3, 16-21. Retrieved from: https:// doi.org/10.30978/UTJ2019-3-16 [in Ukrainian].

12. Clayton, S., Cauble, E., Kumar, A., Patil, N., Ledford, D., Kolliputi, N., Lopes-Virella, M. F., Castell, D., \& Richter, J. (2019). Plasma levels of TNF- $\alpha$, IL-6, IFN- $\gamma$, IL-12, IL-17, IL-22, and IL-23 in achalasia, eosinophilic esophagitis (EoE), and gastroesophageal reflux disease (GERD). BMC Gastroenterology, 19 (1), 28. Retrieved from: https://doi.org/ 10.1186/s12876-019-0937-9

13. Pasiieshvili, T.M. (2019) Autoimmunnaya i vegetativnaya obuslovlennost prolongatsii vosstanovitelnogo perioda u lits molodogo vozrasta s komorbidnostyu gastroezofagealnoy reflyuksnoy boleznyu i autoimmunnogo tyreoidita [Autoimmune and vegetative conditionality of prolongation of recovery period in young patients with comorbidity of gastroesophageal reflux disease and autoimmune thyroiditis]. Klinicheskaya $i$ eksperimentalnaya meditsina - Clinical and Experimental Medicine, 2 (151), 143-146. Retrieved from: https://doi.org/10.29254/20774214-2019-2-2-151-143-147. [in Ukrainian].

14. Jones, B., Kwok, C., \& Kung, A. (1999). Effect of radioactive iodine therapy on cytokine production in Graves' disease: transient increase in IL-4, IL-6, IL-10 and TNF-alpha, with longer term increase in IFN-gamma production. J. Clin. Endocrinol. Metab., 84, 4106-4110.

15. Kharintsev, V.V., Serebryakova, O.V., \& Serkin, D.M. (2016). Rol nekotorykh pro- i protivovospalitelnykh tsitokinov $v$ techenii endokrinnoy oftalmopatii [Role of some pro- and anti-inflammatory citokines in the course of endocrine ophtalmopathy]. Zabaykalskiy meditsinskiy vestnik - Transbaical Medical Bulletin, 2, 33- 40 [in Russian].

16. Jiskra, J., Antošová, M., Límanová, Z., Telička, Z., Lacinová Z. (2009) The relationship between thyroid function, serum monokine induced by interferon-gamma and soluble interleukin-2 receptor in thyroid autoimmune diseases. Clin. Experiment. Immunol. 156, 211-216

17. Sapryna, T.V., Prokhorenko, T.S., Reztsova, V.M. (2012). Osobennosti produktsii i retseptsii tsitokinov Th1/ Th2-profylya pry bolezni Greyvsa [Features of production and reception of cytokines Th1/Th2 profile at Graves' disease]. Klinicheskaya i eksperymentalnaya tyreoidologiya Clinical and Experimental Tyreoidology, 8 (2), 43-49 [in Russian].

18. Popova, E.V., Smolyahyn, A.Y., \& Boev, V.M. (2013). Tsytokinovyy i tyreoidnyy profili pri endemicheskom zobe $u$ lits Yuzhno-Uralskoho regiona [Cytokine and thyroid profiles when endemic goiter in persons of South Ural region]. Tsytokiny i vospalenye - Cytokines and Inflammation, 12 (1), 102-107 [in Russian].

19. Motylewska, E., Nieć, M., Siejka, A., Komorowski, J., Ławnicka, H., Świętosławski, J., Stępień H. (2015) Decreased serum level of IL-7 in patients with active Graves' disease. Cytokine 75 (2), 373-379.

20. Nasonov, E.L., \& Elyseev, M.S. (2016). Rol interleykina $1 \mathrm{v}$ razvitii zabolevaniy cheloveka [The role of interleukin 1 in the development of human disease]. Nauchno-prakticheskaya revmatologiya - Scientific and Pracrical Rheumatology, 54 (1), 60-77 [in Russian].

\title{
РОЛЬ ЦИТОКИНОВОГО ЗВЕНА В РЕАЛИЗАЦИИ ВОСПАЛИТЕЛЬНОЙ РЕАКЦИИ У ЛИЦ МОЛОДОГО ВОЗРАСТА С ГАСТРОЭЗОФАГЕАЛЬНОЙ РЕФЛЮКСНОЙ БОЛЕЗНЬЮ И АУТОИММУННЫМ ТИРЕОИДИТОМ
}

๑Т. М. Пасиешвили

\author{
Харьковский национальный медицинский университет
}

РЕЗЮМЕ. К заболеваниям внутренних органов, при которых воспалительная реакция запускает патогенетическое звено формирования и хронизации нозологии, принадлежат гастроэзофагеальная рефлюксная болезнь (ГЭРБ) и аутоиммунный тиреоидит (АИТ). Их сочетание у лиц молодого возраста, несмотря на доброкачественный характер течения на начальном этапе, в дальнейшем может провоцировать хронизацию процесса и формирование осложнений. Указанные проблемы могут быть следствием изменений в иммунной системе, а именно, цитокинового звена.

Цель - исследовать состояние и изучить роль провоспалительного звена иммунитета по содержанию каспазы-1, ИЛ-1及 и ИЛ-18 при гастроэзофагеальной рефлюксной болезни у лиц молодого возраста с аутоиммунным тиреоидитом.

Материал и методы. В обследовании приняли участие 120 пациентов с ГЭРБ и АИТ и 45 человек с изолированной ГЭРБ в возрасте от 18 до 25 лет. Диагноз АИТ подтверждали повышенным содержанием антител к тиреопероксидазе и тиреоглобулину, а состояние железы - исследованием ее гормонов. Наличие ГЭРБ, наряду с клинической симптоматикой, доказывали проведением ЭФГДС с определением характера поражения слизистой оболочки. Содержание каспазы-1, интерлейкина $1 \beta$ и интерлейкина 18 определяли в сыворотке крови больных иммуноферментным методом.

Результаты. Было установлено, что содержание каспазы-1 в сыворотке крови больных изолированной ГЭРБ в 2,1 раза превышало показатель нормы, и при присоединении АИТ увеличивалось в 2,7 раза. Содержание ИЛ-1 $\beta$ 
Огляди літератури, оригінальні дослідження, погляд на проблему, випадок з практики, короткі повідомлення также превышало показатели контроля в 3,9 и 6,5 раза соответственно. Содержание указанных цитокинов зависело от состояния слизистой оболочки и было максимально увеличенным при наличии эрозивного процесса. Среднее содержание ИЛ-18 в группе с коморбидной патологией превышало показатели нормы почти в 8 раз $(p<0,05)$ против трехкратного увеличения у больных изолированной ГЭРБ.

Выводы. Течение ГЭРБ и АИТ сопровождается повышением синтеза каспазы-1, интерлейкина $1 \beta$ и интерлейкина 18, содержание которых зависит от морфологических изменений в слизистой оболочке пищевода и не коррелирует с функцией щитовидной железы. Повышение интерлейкина 18, кроме участия в провоспалительных процессах, обеспечивает аутоиммунный компонент АИТ, что способствует прогрессированию болезни и формированию осложнений.

КЛЮчЕВЫЕ СЛОВА: гастроэзофагеальная рефлюксная болезнь; аутоиммунный тиреоидит; патогенез; цитокины.

\section{ROLE OF THE CYTOKINE LINK IN THE IMPLEMENTATION OF THE INFLAMMATORY REACTION IN YOUNG PEOPLE WITH GASTROESOPHAGEAL REFLUX DISEASE AND AUTOIMMUNE THYROIDITIS}

\section{Kharkiv National Medical University}

๑T. M. Pasiieshvili

SUMMARY. Gastroesophageal reflux disease (GERD) and autoimmune thyroiditis (AIT) are considered as diseases in which the inflammatory reaction triggers the pathogenetic link in the formation and chronicity of nosology. Their combination in young people, despite the benign nature of the course at the initial stage, can subsequently provoke a chronic process and the formation of complications. These problems may be due to changes in the immune system, namely, the cytokine link.

The aim - to investigate the state and the role of the pro-inflammatory immunity link in the content of caspase- 1 , IL-1 $\beta$ and IL-18 in gastroesophageal reflux disease, in young people with autoimmune thyroiditis.

Material and Methods. The study involved 120 patients with GERD and AIT and 45 people with isolated GERD aged 18 to 25 years. Verification of the AIT diagnosis was performed according to increased content of antibodies to thyroid peroxidase and thyroglobulin. The state of the gland was confirmed by the study of its hormones. The presence of GERD, along with clinical symptoms, was proved by EFGDS with the determination of the state of the mucosal lesion. The content of caspase-1, interleukin $1 \beta$ and interleukin 18 was determined in the blood serum of patients by enzyme immunoassay.

Results. It was found that the content of caspase- 1 in the blood serum of patients with isolated GERD was 2.1 times higher than the norm, while in combination with AIT it increased 2.7 times. The content of IL-1 $\beta$ also exceeded the control indices by 3.9 and 6.5 times, respectively. The content of these cytokines was dependent on the state of the mucous membrane and was maximized in the presence of an erosive process. The average content of IL-18 in the group with comorbid pathology exceeded the norm by almost 8 times against a triple increase in patients with isolated GERD.

Conclusions. GERD and AIT is accompanied by an increase in the synthesis of caspase-1, interleukin 1-and interleukin 18 , the content of which depends on morphological changes in the mucous membrane of the esophagus and does not correlate with thyroid function. The increase in interleukin 18 in addition to participating in the pro-inflammatory process provides the autoimmune component of AIT, which contributes to the progression of the disease and the formation of complications.

KEY WORDS: gastroesophageal reflux disease; autoimmune thyroiditis; pathogenesis; cytokines.

Отримано 11.05.2020 